\title{
PENGARUH MODEL PEMBELAJARAN SAINS TEKNOLOGI MASYARAKAT TERHADAP HASIL BELAJAR IPA DITINJAU DARI LITERASI DIGITAL SISWA KELAS V SEKOLAH DASAR GUGUS VI KECAMATAN MENGWI
}

\author{
D. Jayanti' ${ }^{1}$ I. B. Arnyana ${ }^{2}$, I M. Gunamantha ${ }^{3}$ \\ Program Studi Pendidikan Dasar, Program Pascasarjana \\ Universitas Pendidikan Ganesha \\ Singaraja, Indonesia
}

e-mail: \{dwi.jayanti, putu.arnyana, made.gunamantha\}@pasca.undikhsa.ac.id

\begin{abstract}
Abstrak
Penelitian ini bertujuan untuk mengetahui pengaruh model pembelajaran STM terhadap hasil belajar IPA ditinjau dari literasi digital siswa kelas V sekolah dasar Gugus VI Kecamatan Mengwi. Penelitian ini merupakan kuasi eksperimen dengan rancangan faktorial $2 \times 2$. Data dikumpulkan dengan menggunakan metode tes. Data yang dikumpulkan adalah hasil belajar dan literasi digital. Data dianalisis menggunakan anava dua jalur. Sampel penelitian sebanyak 100 siswa SD di Gugus VI Kecamatan Mengwi. Hasil penelitian ini menunjukkan bahwa: (1) terdapat perbedaan pengaruh yang signifikan antara penerapan model pembelajaran STM dengan model pembelajaran konvensional terhadap hasil belajar IPA ( $\left.F_{\text {hitung }}=5,724 ; p<0,05\right)$; $(2)$ terdapat terdapat interaksi antara model pembelajaran dengan literasi digital dalam pengaruhnya terhadap hasil belajar IPA $\left(F_{A B}\right.$ hitung $=4,430 ; p$ $<0,05)$; (3) terdapat perbedaan hasil belajar pada kelompok siswa dengan literasi digital tinggi yang mengikuti model pembelajaran STM dengan siswa yang mengikuti model pembelajaran konvensional $\left(Q_{\text {hitung }}=19,171 ; \mathrm{p}<0,05\right)$; (4) terdapat perbedaan hasil belajar pada kelompok siswa dengan literasi digital rendah yang mengikuti model pembelajaran STM dengan siswa yang mengikuti model pembelajaran konvensional (Qhitung $=5,703 ; p<0,05$ ). Berdasarkan hasil tersebut, dapat disimpulkan bahwa penerapan pembelajaran model pembelajaran STM dapat berpengaruh secara signifikan terhadap peningkatan hasil belajar pada siswa kelas V di Gugus VI Kecamatan Mengwi ditinjau dari literasi digital.
\end{abstract}

Kata kunci: hasil belajar, literasi digital, model pembelajaran STM

\begin{abstract}
This study aims to determine the effect of science technology and society learning model on science study learning achievement in terms of digital literacy ability of fifth grade students in VI cluster Mengwi subdistrict. This research used quasi experimental with the factorial $2 \times 2$ design. The data was collected using test method. The data was collected using science study achievement and digital literacy ability. The data were analyzed using Anava two way. The research samples are 100 fifth grade students in cluster VI of Mengwi subdistrict. The results of the research show that: (1) there is significant diference of science study achievement between students following science technology and society learning model and those following conventional learning $\left(F_{\text {value }}=5,724 ; p<0,05\right) ;(2)$ there is an interaction effect between learning model and science study achievement towards digital literacy $\left(F_{A B}\right.$ value $=4,430 ; p<$ $0,05)$; (3) there are differences in science study achievement in students who have a high reading interest with students who have high digital literacy ability between students following science technology and society learning model and those following conventional learning $\left(Q_{\text {value }}=19,171 ; p<0,05\right)$; (4) there are differences in science study achievement in students who have a low reading interest with students who have high digital literacy ability between students following science technology and society learning model and those following conventional learning (Qvalue $=5,703 ; p<0,05)$. Based on those findings, it can be concluded that science technology and society learning model implementation has a significant effect on increasing the science study achievement seen from digital literacy ability of fifth grade students in cluster VI Mengwi subdistrict.
\end{abstract}

Keywords: digital literacy, science study, science technology and society learning model 


\section{PENDAHULUAN}

Memasuki abad ke-21, bangsa Indonesia dihadapkan pada berbagai tantangan yang sangat besar. Tantangan yang paling utama, paling mendasar dan paling nyata adalah globalisasi, yang ditandai oleh adanya tingkat persaingan antar negara yang semakin tinggi, terutama kemajuan di bidang ilmu pengetahuan dan teknologi. $\mathrm{Di}$ tengah ketatnya ketidakpastian dan tantangan yang dihadapi setiap orang inilah, maka dibutuhkan perubahan paradigma dalam sistem pendidikan yang harus dapat menyediakan seperangkat keterampilan abad 21 yang dibutuhkan oleh peserta didik guna menghadapi setiap aspek kehidupan global (Soh, Arsad \& Osman, 2010). Perubahan yang dimaksud bukanlah menyangkut perubahan konten kurikulum, melainkan perubahan pedagogi, yaitu perubahan dalam bertindak dari simple action ke arah comprehensive action dan peralihan dominasi pengajaran tradisional menuju pengajaran berbasis teknologi.

Untuk mampu menjawab tantangan globalisasi tersebut, salah satunya diwujudkan melalui pembangunan pendidikan dengan menciptakan sumber daya manusia yang berkualitas. Pendidikan formal merupakan salah satu wadah yang sangat strategis untuk meningkatkan kualitas SDM. Muatan pelajaran yang diajarkan di sekolah diharapkan dapat berkontribusi bagi pengembangan dan peningkatan kemampuan siswa. Salah satu muatan pelajaran tersebut adalah IPA. Pendidikan IPA bagi siswa diharapkan dapat mengembangkan pemahaman, kemampuan, dan sikap ilmiah. Pendidikan IPA sebagai salah satu aspek pendidikan memiliki peran penting dalam peningkatan mutu pendidikan, khususnya di dalam menghasilkan sumber daya manusia yang berkualitas, yaitu manusia yang mampu berfikir kritis, kreatif, mampu dalam mengambil keputusan, dan mampu memecahkan masalah serta mampu mengaplikasikannya dalam kehidupan untuk kesejahteraan umat manusia.

Berbagai upaya telah dilakukan oleh pemerintah untuk meningkatkan kualitas pendidikan IPA pada umumnya. Upaya- upaya tersebut antara lain (1) meningkatkan kualitas tenaga pendidik melalui pelatihan, seminar dan penataran guru-guru, (2) perbaikan dan pemenuhan fasilitas sekolah, dan (3) mengadakan perbaikan kurikulum. Kurikulum terbaru yang diberlakukan pada semua jenjang sekolah di Indonesia saat ini adalah Kurikulum 2013. Namun, upaya peningkatan kualitas pendidikan yang telah dilakukan selama ini masih belum memuaskan, sebagaimana terlihat dalam beberapa indikator. Beberapa indikator yang menunjukkan rendahnya kualitas pendidikan di Indonesia dalam laporan UNDP (United Nation Development Program) tentang peringkat Indeks Pengembangan Manusia (Human Development Index) Indonesia. Indeks Pengembangan Manusia adalah komposisi dari peringkat pencapaian pendidikan, kesehatan, dan penghasilan per kepala. Dari 174 negara di dunia, Indonesia menempati urutan ke-102 pada tahun 1996, ke-99 tahun 1997, ke-105 tahun 1998, ke109 tahun 1999 dan menurun ke urutan 112 pada tahun 2000. Pada tahun 2005, berada pada urutan 110 . Indonesia berada di peringkat 113 di dunia pada tahun 2017 (UNDP, 2017).

$$
\text { Hasil Trends International }
$$

Mathematics and Science Study (TIMSS) terhadap siswa Indonesia grade 8 pada bidang IPA menunjukkan bahwa siswa Indonesia berada pada peringkat 35 dari 49 negara. Siswa Indonesia hanya mampu meraih predikat low international science benchmark (skor minimal 400) dari tiga predikat teratas yaitu intermediate science benchmark (skor minimal 475), high science benchmark (skor minimal 500), dan advance science benchmark (skor minimal 625) (Gonzales et al., 2009).

Berdasarkan fakta di atas terlihat masih rendahnya kualitas pendidikan IPA. Rendahnya kualitas pendidikan tersebut disebabkan oleh pengemasan proses pembelajaran. Proses pembelajaran masih didasarkan pada asumsi bahwa pengetahuan dapat dipindahkan secara utuh dari pikiran guru ke pikiran siswa. Pembelajaran yang terjadi di kelas masih berpusat pada guru (teacher centered). 
Sebaiknya dalam proses pembelajaran di kelas berpusat pada siswa (student centered). Siswa sendiri yang harus membangun pengetahuan di dalam benaknya sendiri. Berdasarkan observasi yang telah dilakukan di SD No. 2 Kapal, terungkap bahwa hasil belajar IPA tergolong cukup rendah (rata-rata nilai siswa sebesar 62,67). Penulis meyakini bahwa guru telah berusaha secara maksimal untuk membelajarkan IPA kepada peserta didiknya. Hanya saja, guru belum menemukan model pembelajaran yang tepat dalam membelajarkan IPA di kelas. Guru masih mengajar dengan deduksi yaitu memberi secara langsung isi materi dan bahkan tidak memberi kesempatan kepada siswa untuk menggali pemahamannya sendiri terhadap materi yang dipelajari (transfer knowledge). Oleh karena itu, diperlukan model pembelajaran yang tepat dalam pembelajaran IPA di sekolah. Salah satu model tersebut adalah pembelajaran model sains teknologi masyarakat (STM). Model pembelajaran sains teknologi masyarakat merupakan model pembelajaran yang mengaitkan antara sains dan teknologi serta manfaatnya bagi masyarakat (Poedjiadi, 2010)

Kekhasan dari model ini adalah bahwa pada pendahuluan dikemukakan isu-isu atau masalah yang ada dimasyarakat yang dapat digali dari siswa, tetapi apabila guru tidak berhasil memperoleh tanggapan dari siswa dapat saja dikemukakan oleh guru sendiri. Tahap ini dapat disebut dengan inisiasi atau mengawali, memulai, dan dapat pula disebut dengan invitasi yaitu undangan agar siswa memusatkan perhatian pada pembelajaran. Apersepsi dalam kehidupan juga dapat dilakukan, yaitu mengaitkan peristiwa yang telah diketahui siswa dengan materi yang akan dibahas, sehingga tampak adanya kesinambungan pengetahuan, karena diawali dengan halhal yang telah diketahui siswa yang sebelumnya yang ditekankan pada keadaan yang ditemui dalam keadaan sehari-hari. Dengan kata lain, model pembelajaran STM merupakan suatu model pembelajaran yang mengaitkan antara sains dan teknologi serta pemanfaatanya bagi masyarakat. Tujuan dari model pembelajaran ini ialah untuk membentuk individu yang memiliki literasi sains dan teknologi serta memiliki kepedulian terhadap masalah masyarakat dan lingkungannya (Lestari, 2016).

$$
\text { Bagi dunia pendidikan, }
$$

perkembangan teknologi tidak terlepas dari adanya perkembangan dalam bidang IPA. Proses perkembangan IPA yang telah dilakukan oleh para ilmuwan IPA membawa dampak positif bagi perkembangan teknologi dengan diciptakannya peralatan yang merupakan produk teknologi. Produk teknologi ini pada gilirannya membawa kemajuan dalam bidang IPA (Septiawan dkk:2014). Produk teknologi juga menimbulkan dampak yang tidak diinginkan baik bagi masyarakat maupun lingkungan. Dampak negatif dari kemajuan teknologi timbul apabila tidak dilandasi dengan pengetahuan dan kemampuan menggunakan produk teknologi tersebut, salah satunya yaitu kurangnya pengetahuan tentang IPA. Pendidikan IPA memiliki peran yang penting dalam menyiapkan siswa memasuki dunia kehidupannya dimana IPA melandasi perkembangan teknologi, sedangkan teknologi menunjang perkembangan IPA (Gusfarenia, 2013).

Mengingat pentingnya peranan teknologi dan keterkaitan dengan pembelajaran IPA, maka sangat penting bagi guru dalam menumbuhkembangkan kemampuan siswa dalam penggunaan teknologi. Literasi digital menjadi bagian dalam mewujudkan gerakan literasi nasional. Literasi digital diartikan sebagai kemampuan untuk memahami dan menggunakan informasi dalam berbagai bentuk dari berbagai sumber yang sangat luas yang diakses melalui piranti computer (Nasrullah, dkk:2017). Terlebih lagi, didukung adanya program laptop dan internet masuk sekolah, khususnya di Kabupaten Badung. Literasi digital sangat penting diberikan dalam kehidupan siswa baik di sekolah, rumah maupun masyarakat. Keberadaan perangkat elektronik seperti handphone, tablet, komputer dan laptop sangat menunjang pelaksanaan literasi 
digital ini. Kemampuan siswa mengakses informasi perlu diupayakan guna mengarah pada pemberdayaan informasi yang lebih baik.

Berdasarkan uraian di atas, upaya meningkatkan hasil siswa terhadap muatan pelajaran IPA diterapkan pembelajaran dengan menggunakan pembelajaran model STM dengan memperhatikan literasi digital yang dimiliki siswa.

\section{METODE PENELITIAN}

Penelitian ini merupakan penelitian kuasi eksperimen. Rancangan penelitian ini adalah rancangan faktorial $2 \times 2$ dengan faktor pemilah (variabel moderator) yakni literasi digital. Rancangan faktorial $2 \times 2$ digunakan untuk menyelidiki secara serempak pengaruh dua variabel perlakuan terhadap kelompok sampel yang diselidiki. Penggunaan desain analisis faktorial $2 \times 2$ pada penelitian ini didasarkan pada asumsi bahwa dua variabel mempunyai pengaruh terhadap variabel lain dan adanya interaksi dari kedua variabel bebas terhadap variabel terikat. Rancangan ini menyediakan peluang untuk menentukan pengaruh utama (main effect) dan pengaruh interaksi (interaction effect) dari variabel-variabel bebas terhadap variabel terikat.

Populasi dalam penelitian ini adalah seluruh siswa kelas $\mathrm{V}$ Sekolah Dasar Gugus VI Kecamatan Mengwi Kabupaten Badung Tahun Pelajaran 2018/2019. Berdasarkan karakteristik populasi tersebut, maka sampling dilakukan dengan teknik random sampling, tetapi yang diacak adalah kelas. Kesetaraan kelas dihitung dengan rata-rata skor tes uji coba, kemudian dilanjutkan dengan menggunakan uji-t. Banyak siswa pada kelas eksperimen dan kelas kontrol sejumlah 100 orang.
Ada tiga jenis variabel yang terlibat dalam penelitian ini yaitu variabel bebas, variabel terikat, dan variabel moderat. Variabel bebas dalam penelitian ini adalah Model Pembelajaran Sains Teknologi Masyarakat dan Pembelajaran Konvensional. Variabel terikat dalam penelitian ini adalah hasil belajar IPA. Sedangkan, literasi digital siswa merupakan variabel moderat.

Dalam penelitian ini data yang diperlukan adalah data tentang hasil belajar IPA dan data tentang literasi digital siswa. Untuk mengukur kedua data tersebut diperlukan tes. Tes yang digunakan untuk mengukur hasil belajar IPA dan literasi digital siswa adalah tes dalam bentuk pilihan ganda.Sebelum instrumen ini digunakan maka dilakukan uji validitas isi dan reliabilitas. Untuk menentukan validitas isi (content validity) dilakukan oleh judges. Instrumen yang telah dinilai oleh judges selanjutnya diuji cobakan di lapangan. Tujuan dari pengujicobaan intrumen adalah untuk menentukan validitas dan reliabilitas instrumen, tingkat kesukaran dan daya beda pada instrumen.

Untuk analisis varian $2 \times 2$ diperlukan beberapa persyaratan analisis yaitu uji normalitas sebaran data dan uji homogenitas varians. Data hasil pengukuran dianalisis secara bertahap sesuai dengan variabel masing - masing untuk menjawab permasalahan penelitian.

\section{HASIL DAN PEMBAHASAN}

Penelitian ini menggunakan desain factorial $2 \times 2$ dengan empat sel perlakuan. Paparan data disajikan dalam deskripsi penyebaran data meliputi rata-rata, standar deviasi, yang disajikan secara lengkap pada Tabel 1 berikut ini.

Tabel 1. Rekapitulasi Hasil Perhitungan Skor Hasil Belajar IPA

\begin{tabular}{|c|c|c|c|c|c|c|c|c|}
\hline $\begin{array}{l}\text { Variabel } \\
\text { Statistik }\end{array}$ & $A_{1}$ & $A_{2}$ & $\mathbf{B}_{1}$ & $\mathbf{B}_{2}$ & $A_{1} B_{1}$ & $A_{1} B_{2}$ & $A_{2} B_{1}$ & $A_{2} B_{2}$ \\
\hline Subjek (N) & 50 & 50 & 50 & 50 & 25 & 25 & 25 & 25 \\
\hline Mean & 18,48 & 16,84 & 18,42 & 16,9 & 20,84 & 16,12 & 16,00 & 17,68 \\
\hline Median & 18,5 & 17 & 18,5 & 17 & 21 & 16 & 16 & 17 \\
\hline Modus & 21 & 17 & 21 & 17 & 21 & 17 & 15 & 17 \\
\hline Std. Deviation & 3,30 & 2,44 & 3,33 & 2,45 & 2,36 & 2,26 & 2,20 & 2,43 \\
\hline Variance & 10,91 & 5,97 & 11,06 & 6,01 & 5,56 & 5,11 & 4,83 & 5,89 \\
\hline
\end{tabular}




\begin{tabular}{|ccccccccc}
\hline Range & 15 & 13 & 14 & 14 & 10 & 10 & 10 & 10 \\
\hline Minimum & 10 & 11 & 11 & 10 & 15 & 10 & 11 & 14 \\
\hline Maximum & 25 & 24 & 25 & 24 & 25 & 20 & 21 & 24 \\
\hline Jumlah & 924 & 842 & 921 & 845 & 521 & 403 & 400 & 442 \\
\hline
\end{tabular}

Keterangan :

\begin{tabular}{|c|c|c|}
\hline$A_{1}$ & $=$ & $\begin{array}{lcc}\text { Kelompok } & \text { siswa yang } \\
\text { mengikuti } & \text { pembelajaran } \\
\text { dengan model } & \text { pembelajaran } \\
\text { STM } & & \end{array}$ \\
\hline $\mathbf{A}_{2}$ & $=$ & $\begin{array}{lll}\text { Kelompok } & \text { siswa yang } \\
\text { mengikuti } & \text { pembelajaran } \\
\text { dengan model } & \text { pembelajaran } \\
\text { konvensional } & \end{array}$ \\
\hline $\mathbf{B}_{1}$ & $=$ & Literasi digital tinggi \\
\hline $\mathbf{B}_{2}$ & $=$ & Literasi digital rendah \\
\hline$A_{1} B_{1}$ & $=$ & $\begin{array}{lrr}\text { Kelompok siswa } & \text { yang } \\
\text { mengikuti } & & \text { model } \\
\text { pembelajaran STM } & \text { dengan } \\
\text { literasi digital tinggi } & \end{array}$ \\
\hline$A_{1} B_{2}$ & $=$ & $\begin{array}{ll}\text { Kelompok } & \text { siswa } \\
\text { mengikuti } & \\
\text { pembelajaran } & \text { STM }\end{array}$ \\
\hline
\end{tabular}

literasi digital rendah

$\mathbf{A}_{2} \mathbf{B}_{1}=$ Kelompok siswa yang mengikuti model pembelajaran konvensional dengan literasi digital tinggi

$\mathbf{A}_{2} \mathbf{B}_{2}=$ Kelompok siswa yang mengikuti model pembelajaran konvensional dengan literasi digital rendah

Pengujian hipotesis dalam penelitian ini menggunakan analisis varian dua jalur. Selanjutnya bila ada interaksi dilanjutkan dengan uji Tukey untuk mengetahui efek interaksi (simple effect) mana yang lebih tinggi. Hasil perhitungan analisis data dengan analisis varian dua jalur dari hasil belajar IPA dalam penelitian ini dapat diikhtisarkan seperti pada Tabel 2 berikut.

Tabel 2. Ringkasan Anava Dua Jalur

\begin{tabular}{ccccccc} 
Sumber & $\mathbf{d k}$ & JK & RJK & & $\mathbf{F}_{\text {hitung }}$ & \multicolumn{2}{c}{$\mathbf{F}_{\text {tabel }}$} \\
${ } }$ & 1 & 144,5 & 144,5 & 5,724 & & $\mathbf{1 \%}$ \\
Antar A & 1 & 124,82 & 124,82 & 4,944 & & \\
Antar B & 1 & 111,83 & 111,83 & 4,430 & & \\
Inter AB & 21 & 530,16 & 25,25 & & & \\
Dalam Kelompok & 24 & 911,31 & & & & \\
TOTAL & 24 & &
\end{tabular}

Berdasarkan hasil perhitungan pada Tabel 2, hasil penelitian dapat diuraikan sebagai berikut.

Pertama, hasil analisis data telah membuktikan bahwa model pembelajaran STM secara signifikan memberikan pengaruh yang berbeda terhadap hasil belajar IPA antara kelompok siswa yang mengikuti pembelajaran dengan model pembelajaran STM dan kelompok siswa yang mengikuti pembelajaran dengan model pembelajaran konvensional. Hal ini ditunjukkan dengan koefisien ANAVA $\left(F_{A}\right)$ sebesar 5,724 yang menunjukkan signifikan terhadap $F_{\text {tabel. }}$ Selanjutnya terbukti bahwa kelompok siswa yang mengikuti pembelajaran dengan model pembelajaran STM dengan skor rata-rata hasil belajar IPA sebesar 18,48 dengan kategori tinggi, lebih tinggi dari hasil belajar IPA pada kelompok siswa yang mengikuti pembelajaran dengan model pembelajaran konvensional dengan skor rata-rata sebesar 16,84 dengan kategori sedang. Sehingga secara umum hasil belajar IPA siswa yang mengikuti model pembelajaran STM lebih baik dari hasil belajar IPA siswa yang mengikuti model pembelajaran konvensional.

Berdasarkan data hasil analisis tersebut, secara teoretis dapat dikatakan bahwa penggunaan model pembelajaran STM berhasil meningkatkan hasil belajar IPA siswa kelas V. Hal ini disebabkan model pembelajaran STM memiliki beberapa keunggulan dibandingkan model pembelajaran konvensional. Pembelajaran dengan model STM melibatkan siswa lebih aktif karena siswa harus mencari sendiri informasi yang digunakan untuk memecahkan masalah. Siswa juga memperoleh kesempatan untuk berperan sebagai decision maker dalam memecahkan masalah. Konsep yang 
dipelajari siswa tidak hanya bersumber dari buku teks tetapi juga dari masyarakat sehingga materi pembelajaran sains dengan model STM dapat melampaui apa yang tertera dalam kurikulum.

Temuan dalam penelitian ini yang menunjukkan bahwa terdapat perbedaan hasil belajar yang signifikan antara kelompok siswa yang melaksanakan model pembelajaran STM dengan kelompok siswa yang melaksanakan model pembelajaran konvensional sesuai dengan penelitian yang dilakukan Suprianto dan S. Ida K. (2016). STM menekankan pengajaran yang lebih mementingkan keterampilan, proses, sistem daripada cakupan isi dan tes. Proses belajar yang dilaksanakan pun berdasarkan atas inisiatif dan tanggung jawab siswa. Siswa berusaha memahami, mencari sumber informasi, serta memecahkan masalah yang diberikan oleh guru. STM membantu mengembangkan kemampuan berpikir peserta didik dalam memecahkan masalah di dunia nyata.

Terlaksananya setiap tahap sangat mendukung dan menentukan keberhasilan pembelajaran secara keseluruhan.. Pembelajaran bersifat fleksibel karena guru leluasa untuk menerapkan berbagai strategi dan metode belajar. Hal ini memberi kesempatan kepada siswa untuk melatih pola pikir yang divergen, kerja kelompok diskusi kelas yang berpusat pada siswa, pemecahan masalah, simulasi, pengambilan keputusan, dan debat dengan menggunakan sumber belajar yang ada di masyarakat.

Kedua, hasil analisis data tentang pengaruh interaksi antara model pembelajaran Sains Teknologi Masyarakat (STM) dan literasi digital siswa terhadap hasil belajar IPA menunjukkan bahwa $F_{A B}$ hitung $=4,430$ lebih besar dari $\mathrm{F}$ tabel $=$ 4,$32 ; F_{A B}=4,430>$ Ftab $=4,32$. Ini berarti bahwa Ho ditolak dan $\mathrm{H} 1$ diterima, sehingga terdapat interaksi antara model pembelajaran dengan literasi digital dalam pengaruhnya terhadap hasil belajar IPA.

Melihat data hasil penelitian tersebut, ditemukan bahwa literasi digital memberi ruang kepada siswa untuk berlatih memahami dan menggunakan informasi dalam berbagai bentuk dari berbagai sumber yang sangat luas yang diakses melalui piranti komputer. Secara konseptual, pendekatan sains teknologi masyarakat (STM) dapat dikaitkan dengan asumsi bahwa sains, teknologi, dan masyarakat memiliki keterkaitan timbal balik, saling mengisi, saling tergantung, saling mempengaruhi dan mendukung dalam mempertemukan antara permintaan dan kebutuhan manusia serta membuat kehidupan masyarakat lebih baik dan mudah. Penggunaan perangkat computer dalam literasi digital memberi kemudahan bagi siswa untuk mengakses informasi berkaitan dengan materi pelajaran. Literasi digital meliputi kemampuan mengakses informasi dari berbagai sumber, mengelola informasi yang diperoleh, mengintegrasikan informasi tersebut, mengambil keputusan, mengadaptasi informasi, serta mengomunikasikan informasi yang diperoleh. Literasi digital yang dimasukkan ke dalam pembelajaran model STM akan memberi pengaruh terhadap hasil belajar IPA siswa kelas V. Pembelajaran STM banyak menggunakan sumber belajar yang ada di masyarakat yang berhubungan dengan materi dan permasalahan teknologi yang akan dikaji.

Ketiga, Berdasarkan hasil analisis uji lanjut menggunakan uji tukey (Tukey's HSD Test) diperoleh perbedaan hasil belajar pada kelompok siswa dengan literasi digital tinggi yang mengikuti model pembelajaran STM dengan siswa yang mengikuti model pembelajaran konvensional sebesar = $19,171\left(Q_{\text {hitung }}=19,171\right)$,. Nilai $Q_{\text {tabel }}$ pada $\alpha$ $=0,05$ dengan derajat kebebasan $\left(\mathrm{n}_{1}+\mathrm{n}_{2}\right.$ 2) $=48$ sebesar $2,83, Q_{1 \text { hitung }}>Q_{\text {tabel }(d b}=48$, $\alpha=0,05$ ). Ini berarti hasil belajar IPA siswa antara kedua kelompok berbeda secara signifikan. Jika dibandingkan rerata hasil belajar antara kedua kelompok diketahui bahwa pada kelompok siswa literasi digital tinggi, nilai rata-rata pada siswa pada yang mengikuti model pembelajaran STM sebesar 20,84 lebih besar dari pada nilai rata-rata pada siswa pada yang mengikuti model pembelajaran konvensional sebesar 16,00. Dengan demikian hasil belajar siswa dengan literasi digital tinggi pada siswa yang mengikuti model pembelajaran STM 
lebih tinggi dari pada siswa yang mengikuti model pembelajaran konvensional.

Model pembelajaran Sains Teknologi Masyarakat (STM) ini merupakan model pembelajaran yang menekankan pada pemberian isu-isu sains teknologi masyarakat yang ada dalam skala lokal, nasional, maupun internasional dan dikaitkan serta dicocokan dengan topik pembelajaran yang dibahas pada pelajaran tersebut. Dan dampak dari pengkaitan dan pencocokan isu-isu tertentu dapat membuat para siswa dapat menumbuhkan sikap bertanggung jawab terhadap lingkungan dan solusi yang diajukan. Model pembelajaran STM memiliki sintaks secara umum dimulai dari sintaks invitasi, eksplorasi, eksplanasi dan solusi, serta tindak lanjut. Seperti halnya pada Fase Invitasi, siswa mampu menggali isu atau masalah lebih dulu dari peserta didik, menghubungkan pembelajaran baru dengan pembelajaran sebelumnya, dan mengidentifikasikan isu atau masalah dalam masyarakat yang berkaitan dengan topik yang dibahas. Selanjutnya, pada fase Eksplorasi, siswa merumuskan pertanyaanpertanyaan spesifik terhadap isu sains dan teknologi yang telah diidentifikasikan, berlatih keterampilan proses sains, dan diskusi kelompok untuk menghasilkan kesimpulan. Fase Eksplanasi dan Solusi, memberi kesempatan kepada siswa membangun konsep dan mengemukakan solusi masalah yang dihadapi masyarakat terkait materi yang diperoleh siswa sematamata berdasarkan informasi dari kegiatan eksplorasi. Selanjutnya, Fase Tindak Lanjut siswa menjelaskan fenomena alam berdasarkan konsep yang disusun sesuai permasalahan yang telah ditemukan.

Literasi digital siswa dilatihkan pada setiap tahapan kegiatan pembelajaran seperti halnya pada tahapan research, dan tahapan communication. Pada tahap research, siswa dapat menggunakan media internet sebagai sumber informasi. Bagi siswa yang belum memiliki kecakapan literasi digital dengan baik akan kesulitan menemukan kata kunci guna mendapatkan informasi yang relevan sesuai dengan proyek yang dikerjakan. Penggunaan berbagai perangkat pencari juga menunjukkan tingkat literasi digital siswa. Kemampuan untuk melakukan acces juga berpengaruh terhadap kevalidan informasi yang diterima. Begitu pula pada tahapan communication, siswa dilatih untuk mampu mengkomunikasikan hasil temuan kedalam bahasa lisan maupun tulisan. Pemilihan perangkat, melakukan proses rekam, dan unggah juga merupakan bagian dari kecakapan literasi digital siswa. Dengan kecakapan literasi digital, siswa dapat memilih, memilah, dan menggunakan informasi serta menilai pesan media dengan penuh kesadaran dan bertanggungjawab (Silvana, 2017). Tumbuhnya kesadaran ini tentu dapat membudayakan generasi muda dalam melakukan filtrasi terhadap konten-konten yang beredar di dunia digital.

Bagi siswa dengan literasi digital tinggi, tahapan pembelajaran pada model STM ini mampu mendorong siswa berfikir kritis dan mampu memecahkan masalah dengan cara diberi permasalahan dalam pembelajaran, dipancing bertanya, dan berupaya mencari pemecahan masalah dengan mencari berbagai informasi melalui internet. Selain itu, siswa dilatih untuk memahami dan mengkomunikasikan ide. Setelah memahami apa yang dipelajari, siswa didorong untuk membagikan ide-ide yang telah menjadi gagasan-gagasan sebagaimana yang telah diperolehnya melalui kegiatan literasi. Kemampuan bekerjasama dalam melakukan pekerjaan bersama orang lain, oleh karena itu dengan literasi digital siswa dilatih untuk bekerjasama dengan orang lain, kelompok lain, bidang lain, dengan cara berbagi informasi dan pengalaman melalui media komputer.

Implementasi program literasi digital diharapkan dapat mendorong siswa dan warga sekolah lainnya dalam mendukung keterampilan Abad 21, sebagaimana dijelaskan penggunaan komputer untuk mendukung 4C (Zoraini, 2014), The Four Cs of 21st Century Skills, yaitu (1) Critical Thinker, peserta didik didorong untuk berfikir kritis dan mampu memacahkan masalah dengan cara diberi permasalahan dalam pembelajaran, dipancing bertanya, dan berupaya mencari pemecahan 
masalah dengan mencari berbagai informasi melalui internet; (2) Communicator, peserta didik dilatih untuk memahami dan mengkomunikasikan ide. Setelah memahami apa yang dipelajari, peserta ddik didorong untuk membagikan ide-ide yang telah menjadi gagasangagasan sebagaiman apa yang telah diperolehnya melalui kegiatan berliterasi; (3) Collaborator, kemampuan bekerjasama dalam mekukan pekerjaan bersama orang lain, oleh karena itu dengan literasi digital perserta didik dilatih untuk beker sama dengan orang lain, kelompok lain, bidang lain, denganc ara berbagi informasi dan pengalaman melalui media komputer; (4) Creator, kemampuan menjadi kreator sangan diperlukan untuk menghasilkan pekerjaan dengan kualitas tinggi. Gerakan literasi digital di kelas kegiatan literasi sekolah sekarang sudah mulai bergeser dari literasi baca tulis konvensional dengan menggunakan media cetak ke media elektronik yang lazim disebut literasi digital.

Keempat, berdasarkan hasil analisis uji lanjut menggunakan uji tukey (Tukey's HSD Test) diperoleh perbedaan hasil belajar pada kelompok siswa dengan literasi digital rendah yang mengikuti model pembelajaran STM dengan siswa yang mengikuti model pembelajaran konvensional sebesar $=5,703\left(Q_{\text {hitung }}=\right.$ $5,703)$. Nilai $Q_{\text {tabel }}$ pada $\alpha=0,05$ dengan derajat kebebasan $\left(n_{1}+n_{2}-2\right)=48$ sebesar 2,83, $Q_{1 \text { hitung }}>Q_{\text {tabel }}(\mathrm{db}=48, \alpha=0,05)$. Ini berarti hasil belajar IPA siswa antara kedua kelompok berbeda secara signifikan. Jika dibandingkan rerata hasil belajar antara kedua kelompok diketahui bahwa pada kelompok siswa literasi digital rendah, nilai rata-rata pada siswa pada yang mengikuti model pembelajaran STM sebesar 16,12 lebih kecil dari pada nilai rata-rata pada siswa pada yang mengikuti model pembelajaran konvensional sebesar 17,68. Dengan demikian hasil belajar siswa dengan literasi digital rendah pada siswa yang mengikuti model pembelajaran STM lebih rendah dari pada siswa yang mengikuti model pembelajaran

Konvensional.

Warpala (2015) menyatakan bahwa model pembelajaran konvensional adalah model pembelajaran yang lazim dilakukan oleh guru dalam kesehariannya mengajar di kelas. Model pembelajaran konvensional merupakan model pembelajaran yang bersifat linier dan sudah lazim diterapkan dalam pembelajaran sehari-hari. Ini berarti bahwa model pembelajaran konvensional adalah model pembelajaran yang memang secara rutin dilakukan oleh guru dalam pembelajarakan materi dalam kelas dan pembelajaran masih bersifat linier dari satu bagian ke bagian yang lain. Pembelajaran yang berlaku di sekolah saat ini pembelajaran dilakukan di kelas berorientasi pada tahap-tahap pembukaanpenyajian-penutup. Menurut Arnyana (2004) model pembelajaran konvensional memiliki ciri-ciri sebagai berikut: (1) adanya tujuan pembelajaran dan pengaruh model pada siswa termasuk prosedur penilaian hasil belajar, (2) sintak atau alur kegiatan pembelajaran, dan (3) sistem pengelolaan dan lingkungan belajar model yang diperlukan agar kegiatan pembelajaran tertentu dapat berlangsung dengan berhasil.

Siswa yang memiliki literasi digital yang rendah cendrung untuk mengikuti tujuan pembelajaran apa adanya, sehingga memerlukan teori dan contoh penyelesaian suatu masalah sesuai dengan apa yang disajikan guru. Akibatnya materi pembelajaran yang disajikan dengan teori, contoh dan pelatihan sangat menguntungkan siswa yang mempunyai literasi digital rendah. Model pembelajaran konvensional bertujuan mengajarkan dua macam pengetahuan yaitu pengetahuan deklaratif dan pengetahuan prosedural (Depdiknas, 2004; Arnyana, 2007; Trianto, 2007). Ditegaskan pula bahwa model ini dirancang secara khusus untuk meningkatkan hasil belajar siswa tentang pengetahuan deklaratif dan pengetahuan prosedural yang terstruktur dengan baik dan dapat dipelajari selangkah demi selangkah. Sebaliknya mereka mengalami kesulitan bila materi pembelajaran dimulai dari mengungkapkan ide atau gagasangagasan awal, menyusun jawaban dan menyimpulkan sendiri hasilnya, karena harus mengkonstruksi sendiri pengetahuannya. 
Berpijak pada kegiatan dalam pembelajaran langsung bagi siswa yang memiliki literasi digital rendah wajar apabila hasil analisis statistik menunjukkan bahwa bagi siswa yang memiliki literasi digital rendah dan mengikuti pembelajaran dengan model pembelajaran konvensional memiliki hasil belajar yang lebih tinggi dari pada siswa yang mengikuti pembelajaran dengan model pembelajaran STM. Temuan ini sesuai dengan penegasan Ibrahim (2002) bahwa: "Bagi siswa yang memiliki literasi rendah adanya suatu inovasi tidak akan membangkitkan semangat belajar mereka, sehingga berpengaruh terhadap hasil belajar yang mereka capai".

Upaya peningkatan literasi digital dalam proses pembelajaran dengan model pembelajaran STM bagi siswa terutama siswa yang memiliki literasi digital rendah adalah menyampaikan pentingnya teknologi informasi di era pendidikan sekarang. Di tengah gencarnya arus informasi teknologi, siswa memiliki peran penting dalam menyikapi informasi yang bereder di internet guna menghindari informasi-informasi yang tidak benar. Dengan menyadari peran siswa dapat mebangkitkan minat/motivasi diri dalam meningkatkan literasi digital.

Pembelajaran STM yang memberi ruang terhadap penggunaan piranti komputer baik hardware maupun software serta akses internet berdampak pada peningkatan kemampuan siswa untuk melek terhadap perkembangan teknologi digital. Perangkat komputer/laptop maupun smartphone digunakan siswa sebagai media belajar. Tidak hanya pada siswa, guru juga dituntut untuk memahami penggunaan piranti tersebut. Dalam kaitannnya dengan pembelajaran, perangkat digital tersebut menjadi wahana dalam pemberian tugas terstruktur kepada siswa melalui tugas rumah. Penggunaan perangkat ini yang sudah terarah dapat mengurangi dampak negatif seperti penggunaan game online, dan aktivitas sosial media.

\section{PENUTUP}

Berdasarkan empat temuan dari hasil pengujian hipotesis seperti disajikan pada bab IV, maka dalam penelitian ini diperoleh empat simpulan sebagai berikut.

1. Temuan penelitian menunjukkan bahwa terdapat pengaruh perbedaan yang signifikan antara penerapan model pembelajaran STM dengan model pembelajaran konvensional terhadap hasil belajar IPA.

2. Temuan penelitian menunjukkan bahwa terdapat terdapat interaksi antara model pembelajaran dengan literasi digital dalam pengaruhnya terhadap hasil belajar IPA

3. Temuan penelitian menunjukkan bahwa terdapat perbedaan hasil belajar pada kelompok siswa dengan literasi digital tinggi yang mengikuti model pembelajaran STM dengan siswa yang mengikuti model pembelajaran konvensional

4. Temuan penelitian menunjukkan bahwa terdapat perbedaan hasil belajar pada kelompok siswa dengan literasi digital tinggi yang mengikuti model pembelajaran STM dengan siswa yang mengikuti model pembelajaran konvensional

\section{DAFTAR RUJUKAN}

Arnyana, I.B. 2004. Pengembangan Perangkat Model Belajar Berdasarkan Masalah Dipandu Strategi Kooperatif serta Pengaruh Implementasinya terhadap Kemampuan Berpikir Kritis dan Hasil Belajar Siswa Sekolah Menengah Atas pada Pelajaran Ekosistem. Disertasi (tidak diterbitkan). Malang : Universitas Negeri Malang Program Pascasarjana Program Studi Pendidikan Biologi

Gonzales, P., Leslie, J., Stephen, R., David, K., \& Summer, B. 2009. Highlight from TIMSS 2007: Mathematics and science achievement of u.s fourth-and eighth-grade students in an international context. Institute of education Science. Tersedia pada http://nces.ed.gov/pubs2009/2009001. pdf. diakses pada 3 Nopember 2018

Gusfarenia, D. 2013. Model Pembelajaran Sain Teknologi Masyarakat (STM). Jurnal Edu- Bio 4: 21-31. 
Lestari, dkk. 2016. Penerapan Model Pembelajaran Sains Teknologi Masyarakat (STM) untuk Meningkatkan Hasil Belajar Fisika Siswa Kelas VIII SMPN 3 Mataram. Tersedia pada Jurnal Pendidikan Fisika dan Teknologi (ISSN. 24076902) Volume II No 3, Juli 2016

Nasrullah, dkk. 2017. Materi Pendukung Literasi Digital. Jakarta: Kemdikbud.

Poedjiadi, A. 2010. Sains Teknologi Masyarakat Model Pembelajaran Kontekstual Bermuatan Nilai. Remaja Rosdakarya: Bandung.

Silvana dan Cecep. 2017. Pendidikan Literasi Digital di kalangan Usia Muda di Kota Bandung. Termuat pada Jurnal PEDAGOGIA: Jurnal IImu Pendidikan UPI

Soh, T., Arsad, N., \& Osman, K. 2010. The relationship of 21st century skills on students' attitude and perception towards physics. Procedia Social and Behavioral Sciences, 7(C), 546-554

Suprianto dan S. Ida K. 2016. Pengaruh

Penerapan Pendekatan

Pembelajaran Sains Teknologi Masyarakat (STM) terhadap Peningkatan Hasil Belajar Siswa di SMA Hidayatun Najah". Tersedia pada Jurnal Gravity (Jurnal IImiah Penelitian dan Pembelajaran Fisika) Vol. 2 No. 1 (2016)

UNDP Indonesia, Indonesia Human Development Report. 2017. The Economics Democracy: Financing Human Development in Indonesia. Published Jointly by BPS-Statistic Indonesia.

Warpala, I W. S. 2015. Pengaruh Pendekatan Pembelajaran dan Strategi Belajar Kooperatif yang Berbeda Terhadap Pemahaman \& Keterampilan Berpiikir Kritis dalam Pembelajaran IPA SD. Disertasi. Malang: PPS Universitas Negeri Malang 